\title{
Educational Reform of College English Course on the Background of ESP
}

\author{
Huili Liu \\ Teaching and Research Institute of Foreign Languages, Bohai University, Jinzhou, 121013, China \\ 969013976@qq.com
}

Keywords: ESP; English for specific purpose; college English; educational reform

\begin{abstract}
With the development of economic globalization, English as an important tool of communication application is more and more widely. The traditional college English teaching could not meet the needs of multi-level, many colleges and universities through the ESP courses to train complex talents. This paper researches on the problems existing in the current college English teaching. First, the ESP professional competence; Secondly, analysis the necessity of ESP teaching; Then, the ESP teaching curriculum design; Finally, the Suggestions of teaching reform, specific include: comprehensive reform, perfecting the assessment mechanism, attaches great importance to the teaching material write, enrich the teaching methods and means, etc. Practical application of this article research results, combined with the characteristics of the school and students, teaching reform in order to make more productive.
\end{abstract}

\section{Introduction}

From the point of currently teaching English in China, taking (English for General Purposes) and ESP (English for Specific Purpose) as the two mainstream of English teaching and research. Taking a refers to the basic knowledge of English, a professor at the school, emphasize the students understand the basic English language structures, vocabulary and grammar, to cultivate students in listening, speaking, reading, writing and translation of the five basic skills, is needed for daily life language. In taking a teaching method of training, the students can communicate, deal with ordinary language proficiency test [1].From the high school English teaching in China are belong to the category of common use English teaching, teaching mode of taking out the whole process of basic education. The current college English teaching is also belongs to taking mode.

ESP is relative to the taking of a kind of teaching mode, based on the theory of functional view of language, according to the needs of the learner's particular purpose and specific courses in English. ESP focus on how to efficiently combine language use and language learning, is a continuation of the basic English teaching or extension, is the development of the students' language knowledge and skills to a certain stage, in view of the students' actual needs, to further develop the students' language ability is an important teaching content, a taking teaching have a clear purpose and targeted.

EGP and ESP is two kinds of English language teaching mode, the actual refers to the two different stages of learning English, in the process of public English teaching is a continuum. Taking cultivating the students' language ability, GSP pays attention to cultivate students "communicative competence"; Taking emphasize foundation, ESP application is emphasized. Taking a major to cultivate the students' basic English skills, ESP mainly trains the student to use English in a professional work environment of communication skills. The teaching goal is different, both in the setting of curriculum content, teaching means and so on also has a qualitative difference.

\section{Professional Competence Structure of ESP}

Professional ability generally refers to the specialized knowledge, professional skills and special ability is directly related to professional ability, the basis of is to conduct the basic conditions of professional activities. As a contemporary college students, in addition to basic ability, must also has professional ability and professional foreign language ability. This is the point of winning 
performance improvement, without this support, career, there is no development potential. Professional ability is reflected in daily work, such as management, concerning foreign affairs or business activities. Both have the basic quality and basic ability to support, need professional knowledge and ability to accumulate more. ESP professional competence is shown in Fig.1.

\begin{tabular}{|c|c|c|}
\hline & & Understand the professional English general session \\
\hline & Listening skills of & Command of English listening \\
\hline & & Understand simpler professional materials \\
\hline & & Can perform simple English conversation \\
\hline & Conversational skills & Master professional English conversational skills \\
\hline a & & Have access to and request such as communication skills \\
\hline 䓀 & & Form a higher reading logical thinking \\
\hline రิ & Reading skills of & Absorb more professional background knowledge \\
\hline స్రี兀 & professional English & Close reading, skimming and consult \\
\hline 离 & & Master the ability to obtain information from the network \\
\hline to & & Master professional English translation \\
\hline & Translation skills of & The basic theory of bilingual translation \\
\hline & professional English & Master professional English long sentence translation \\
\hline & & Master professional English translation skills \\
\hline & & Collection of literature material ability \\
\hline & & All the literature materials ability \\
\hline & Writing skills of & According to the material to determine the subject ability \\
\hline & professional English & Organize the material and the formation of a text \\
\hline & & The ability to use professional symbols accurately \\
\hline & & Have professional organizations written ability \\
\hline
\end{tabular}

Fig. 1. Professional competence structure of ESP

\section{Necessity of ESP Teaching}

College English teaching is an integral part of higher education, college English course is a required basic course of college students. College English is a foreign language teaching theory as the guide to English language knowledge and application skills, cross-cultural communication and learning strategy as the main content, and collect a variety of teaching mode and teaching means for the integration of teaching system. The teaching aim of college English is to cultivate the students' English comprehensive application ability, especially listening and speaking skills, to make them in the future study, work and social activities can communicate effectively in English, at the same time to improve their ability of autonomous learning, improve the comprehensive cultural quality, to meet the need of social development in our country and international communication. The necessity of ESP teaching in college English is as follows:

(1) The ESP teaching is an objective demand to improve the language application ability. One of the functions of language is communication of daily life as the carrier of human civilization and knowledge. Language is the access to information, learning and mastering foreign advanced science and technology is the most direct and fast bridge and approach. Basic English teaching is an important stage in college English teaching, cannot achieve the purpose of their major, the ultimate 
goal of college English teaching is to help students make the transition from language learning to use language, ESP teaching is to complete this transition.

(2) Carry out the ESP teaching is the objective demand of students to improve their professional ability. From the perspective of the students through the basic stage of English learning, students have had the basic language skills, have the ability of the ESP training. Students in the process of applying and practice, and gradually realize English ability and professional knowledge, be short of one cannot, and must be through language behavior to improve language ability, therefore, have strong request for ESP teaching.

(3) The ESP teaching is the objective requirement of social development. With the society development, society's need for foreign language skills has become increasingly specialized, professional foreign trade to have the ability to direct business negotiations in English, journalism graduates must have the ability to direct interview in English, tourism graduates to have direct guide in English ability,..., ESP teaching in colleges and universities, to improve students' English application ability has become the objective requirement of the development of modern society.

\section{Teaching Curriculum Design of ESP}

Curriculum design is according to the different teaching objects, in view of the different levels of teaching and learning process, different scope, different links and different forms of design, use of different discipline theory system to solve the problem of foreign language teaching. Course is designed to consider the process to make study plan, you need to consider the learners, teachers and teaching environment and so on various aspects, includes the teaching goal, teaching implementation and teaching evaluation, etc. Curriculum design is a key link in the process of ESP teaching, directly affects the teaching goal, teaching method and teaching effect.

Course design of starting to ask questions, answer can be used as a design outline, teaching materials, teaching and evaluation process. Questions include [2]:

Why: Why do students need to learn?

Who: Who will be involved in curriculum design?

Where: Learning place is in Where?

When: When did you learn? How much study time? How to allocate time to study?

What: What students need to learn? You have to learn what respect? How do you determine the learning objectives? What kind of proficiency must be reached? What topics to cover?

How: How to get learning? Based on learning theory? Which learning method is used?

Including three ESP course design mode, with the center of language curriculum design patterns, skills centered curriculum design patterns and learning centered curriculum design mode. College English ESP teaching mode is more suitable for learning centered, as shown in Fig.2 [3].

Learning centered curriculum design model and its requirements analysis of the "learner" include learning, learning situation, target scene and language. According to the analysis of the concept of learning and learning situation, determine the learners' attitude and potential, and to determine the teaching situation of requirements and constraints. According to the target scene and language view, determine the skills and knowledge for the target scene. On this basis, the writing outline and teaching materials, to develop the potential of learning situation, the knowledge and skills required to master the target scene. Finally, evaluating the outline, the material, the students gain the knowledge and skills, used to analysis again, on the "learner" course design become the process of dynamic cycle.

\section{Educational Reform Proposal of College English Course on the Background of ESP}

ESP teaching method helps to improve the effect of college English teaching reform. Under the background of the ESP college English curriculum reform proposal as follows [4-7]:

(1) Comprehensive reform. Can try task teaching method in the process of ESP teaching and group cooperation teaching method and so on all kinds of excellent English teaching methods; 
Focus on ESP teaching and practice teaching, the combination of the development of ESP teaching can be outside of the classroom, combining with professional practice activities, so that the students English practical application in the post practice exercise ability; ESP teaching should make full use of multimedia and network teaching, the creation of related to students' situation, make the class more vivid and improve the students' interest and teaching effect.

(2) Improve the assessment mechanism. Scientific and reasonable evaluation mechanism is an important technique to examine the effects of ESP teaching, also is the necessary condition to ensure ESP teaching smoothly. The current exams for more standardized written, testing types mainly reading comprehension and English-Chinese translation, is not conducive to students and improve the ESP application. Must improve the evaluation mechanism, implement the combination of summative assessment and formative assessment, increase the oral form, add the case study, group discussion, and oral defense assessment of a variety of ways, for ESP teaching play a supporting role.

(3) Attaches great importance to the textbook. Organization the authority of experts and professors to produce relevant professional teaching materials, let students understand the basic language rules and ESP need English skill, at the same time writing involves the professional discipline specific knowledge of auxiliary materials, make the students and the use of normative and practical teaching material, so as to improve the learning efficiency of ESP courses and learning effect. Writing teaching material should follow the following principles: content is scientific and advanced, closely integrated with professional, reflect the law of language teaching and learning, in line with the students' learning interest, highlight the diversification and individuation.

(4) The rich teaching methods and means. "Student-centered" teaching, using the simulation method, case teaching, and role playing method and so on the many kinds of teaching methods, make students really involved in the classroom teaching activities; Using modern education technology, to create a real language environment, will be the real social scene into the classroom; Using face-to-face practice base, increase the proportion of practical teaching link; Use of abundant network resources for independent learning, let students understand the development of the discipline of dynamic and cutting-edge knowledge.

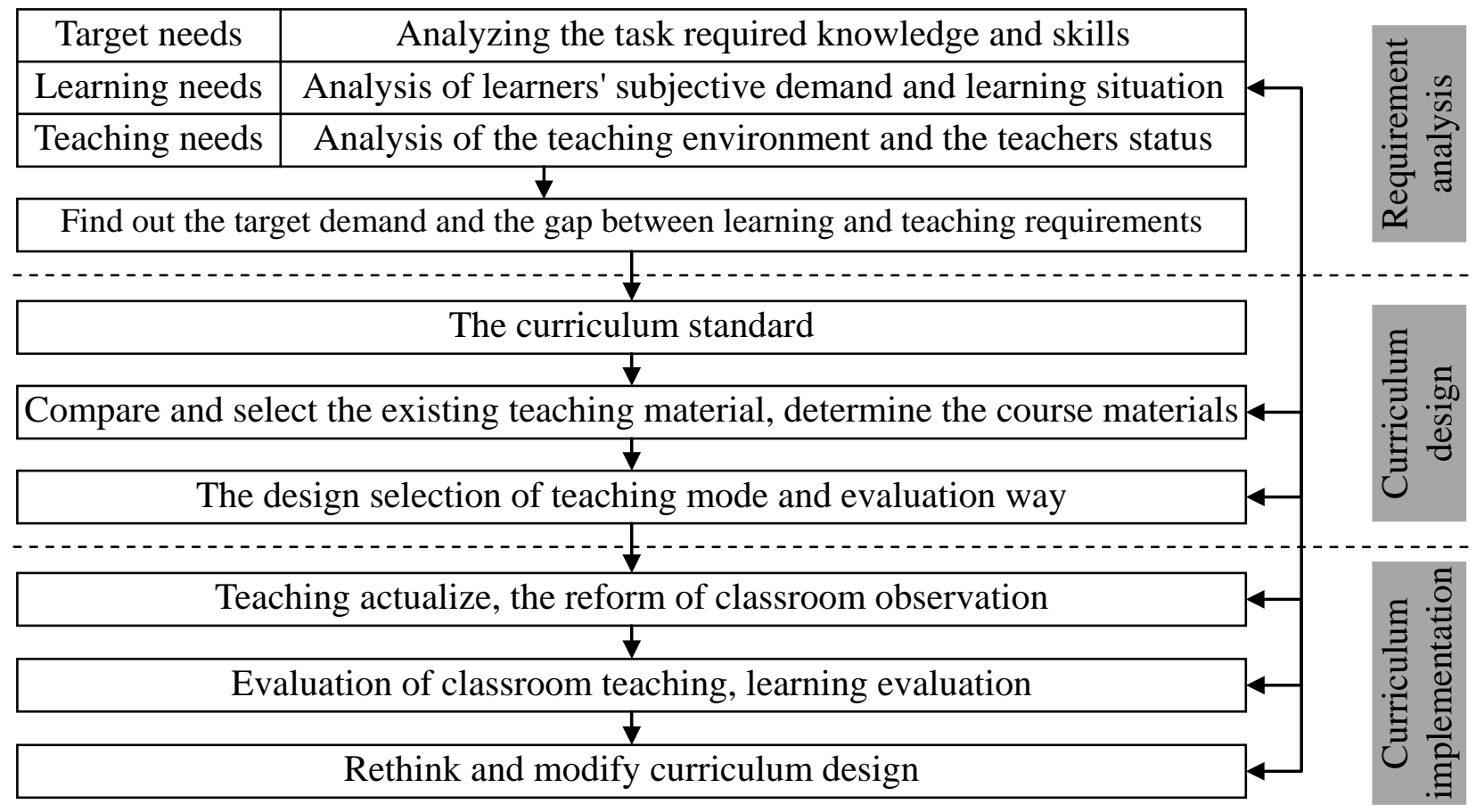

Fig. 2. Learning centered ESP teaching college English curriculum design patterns

\section{Conclusion}

Taking both as teaching goal and teaching content EGP and ESP is complement each other, close 
contact between them, an integral, there are both connection and difference. Taking embodies the language of humanity, ESP embodies the language tool. College English teaching reform, both are associated with humanism, and combined with utilizable, all reflects the use of a language. Because the student's career goals, learning conditions and different levels, different level universities in ESP teaching each have different needs and characteristics, this paper research on the college English teaching reform has guiding significance.

\section{References}

[1] Q. Sun, "Measures and Suggestions on ESP Teaching for Cultivating Interdisciplinary Talents," Journal of Shenyang University (Social Science), vol. 16, no. 5, pp. 651-653, 2014.

[2] T. Tian, "Some thoughts on ESP course design in undergraduate colleges," Journal of Sanjiang University, vol. 5, no. 1, pp. 47-52, 2009.

[3] H. L. Qiao, "Higher Vocational ESP Curriculum Design Based on Needs Analysis," Master's degree of Nanjing Normal University, 2015.

[4] D. E. Zhang, Y. Z. Wang, "On the teaching reform of college English teaching: from EGP to ESP," Heilongjiang Researches on Higher Education, vol. 33, no. 7, pp. 164-167, 2014.

[5] L. Zhou, "Restriction factors and development suggestions of ESP teaching in higher vocational education," Education Teaching Forum, vol. 8, no. 12, pp. 279-280, 2016.

[6] Y. Wang, "On the Problems in Chinese ESP Teaching and the Suggestions for Its Reform," Journal of the Qiannan Normal College for Nationalities, vol. 32, no. 6, pp. 58-60, 2012.

[7] R. Li, W. Xie, "Review on the Research of Moral Education in Higher Vocational Colleges," Journal of Xingtai Polytechnic College, vol. 31, no. 6, pp. 17-19, 2014. 